\title{
Inland Aquaculture and Fish Health Management: A Case Study of Sylhet District in Bangladesh
}

\author{
Anik Deb ${ }^{1}$, Chironjib Singha Samanta Chandan ${ }^{2, *} \mathbb{D}$, Puja Roy ${ }^{2}, \mathrm{Md}$. Istiaque \\ Hossain $^{3}$, Sayed Mashequl Bari ${ }^{4}$
}

${ }^{1}$ Sylhet Agricultural University, Fish Health Management, Sylhet, Bangladesh.
${ }^{2}$ Sylhet Agricultural University, Fish Biology and Genetics, Sylhet, Bangladesh.
${ }^{3}$ University of Rajshahi, Department of Fisheries, Rajshahi, Bangladesh.
${ }^{4}$ Aquatic Animal Health Management, Sher- e- Bangla Agricultural University, Dhaka, Bangladesh.

How to cite

Deb, A., Samanta Chandan, C.S., Roy, P., Hossain, M.I., Bari, S.M. (2021). Inland Aquaculture and Fish Health Management: A Case Study of Sylhet District in Bangladesh. Aquaculture Studies, 21, 129-137. http://doi.org/10.4194/2618-6381-v21_3_05

\section{Article History}

Received 01 September 2020

Accepted 17 March 2021

First Online 23 March 2021

\section{Corresponding Author}

Tel.: -

E-mail: chironjib.chandan@gmail.com

\section{Keywords}

Farm management

Fish health

Fish diseases

Inland water

Aquaculture of Bangladesh

\begin{abstract}
The inland aquaculture of Bangladesh has been intensified recently; however decreased total inland production was also observed in few regions, including the Sylhet district. Therefore, the study was conducted to assess the condition of inland aquaculture and fish diseases in 36 aquaculture farms (Sylhet, Bangladesh) through questionnaire interviews and focus group discussions among farm stakeholders $(n=216)$. There was no significant Upazilla-wise variation considering different parameters $(P>0.05)$, except expenditure to prevent diseases. However, farms of medium and large size spent high to prevent diseases $(P<0.05)$; this expense seems to make better farming conditions. In contrast, smaller farms were observed to have higher stocking density and production $(P<0.05)$. Though different traditional and commercial chemicals and medicines were applied to prevent diseases and maintain water quality, respondents mentioned outbreaks of several diseases. Most respondents perceived financial help, proper training, and technical support could improve farming practices. Overall, public farms with well trained and experienced managers seemed to have better farming conditions than private farms.
\end{abstract}

\section{Introduction}

Aquaculture is one of the fastest-growing foodproducing sectors globally, acts as an effective contributor to fulfil the nutritional requirement, and eradicate poverty. The total production from aquaculture was 80 million tons in $2016,47 \%$ of the world's total fisheries production and catch. More than half of this production from aquaculture belonged to inland aquaculture (FAO, 2018). Asian developing countries, e.g., China, India, Bangladesh, Myanmar, Indonesia, and Cambodia, are well ahead of others in utilizing their inland water bodies (FAO, 2018). In Bangladesh, small-scale inland aquaculture farming has been evolved with multiple numbers of aquaculture practices, techniques, and cultured fish species. In fact, the production from inland aquaculture was 2.4 million metric tons in 2017-18, which was $56 \%$ of the total fisheries production of Bangladesh. In the same year, inland aquaculture undoubtedly helped to make the country self- sufficient in producing fish with an average of $62.58 \mathrm{~g}$ per person in daily diet. Besides, about 1.2 million people in Bangladesh earn their livelihood from the inland fisheries sector (DoF, 2018). Successful aquaculture practices can be very beneficial; as a result, increased interests in fish farming have been observed in different areas of Bangladesh. However, several obstacles may hinder the path of success in aquaculture- 
disease outbreak in reared animals is one of the main culprits. Although fish farms have adopted different health management techniques in several aquaculture farms of Bangladesh (Faruk et al., 2004; Rahman, 2014), several studies also mentioned the prevalence of various diseases such as epizootic ulcerative syndrome, dropsy, argulosis, tail and fin rot, hypoxia, and nutritional disease in cultured fish in farms of few other districts with widespread aquaculture in Bangladesh (Faruk et al., 2004; Hasan et al., 2013; Aftabuddin et al., 2016). The aquaculture production in most of the districts in Bangladesh increased recently compared to the past (DoF, 2018). However, the total production from inland waters of Sylhet district seemed to become steady from 2014-15 to 2017-18, and a surprising fall was observed in 2018-19 compared to the previous years (Figure 1). It was estimated in previous studies that about $6-7 \%$ of surveyed fish farms in Bangladesh suffered a severe loss; the common reason for this incident included disease outbreaks and mass mortality (Alam \& Guttormsen, 2019; Brown \& Brooks, 2002). Therefore, it is crucial to understand the overall condition of the aquaculture farms of Sylhet district for decision-making and future planning for improving inland production and reducing disease outbreak. Besides, very few studies have illustrated the aquaculture farm practices in a region of growing interest for inland fish farming like Sylhet. Therefore, the fish farms from the Upazilla containing the required amount of aquaculture farms (12) in Sylhet, as an emerging aquaculture district in Bangladesh, were assessed to identify the aquaculture farm conditions and health management strategies by studying the condition and perception of managers and farmers, culture practices and techniques, annual production, observed diseases, and health management.

The objective of this experiment was to assess some basic input and output of inland aquaculture farms of Sylhet district.

\section{Materials and Methods}

\section{Area of Study}

The experiment was conducted in 36 aquaculture farms that were selected randomly located in 12 Upazilla (Balaganj, Beanibazar, Bishwanath, Companiganj, Dakshin Surma, Fenchuganj, Golapganj, Gowainghat, Jaintiapur, Kanaighat, Sylhet Sadar, and Zakiganj; three farms in each Upazilla) of the Sylhet district (Figure 2) for about six months from January to June 2018. The target group was the farmers/farm workers ( $n=180$, five from each farm) associated with those farms and their respective managers $(n=36$, one

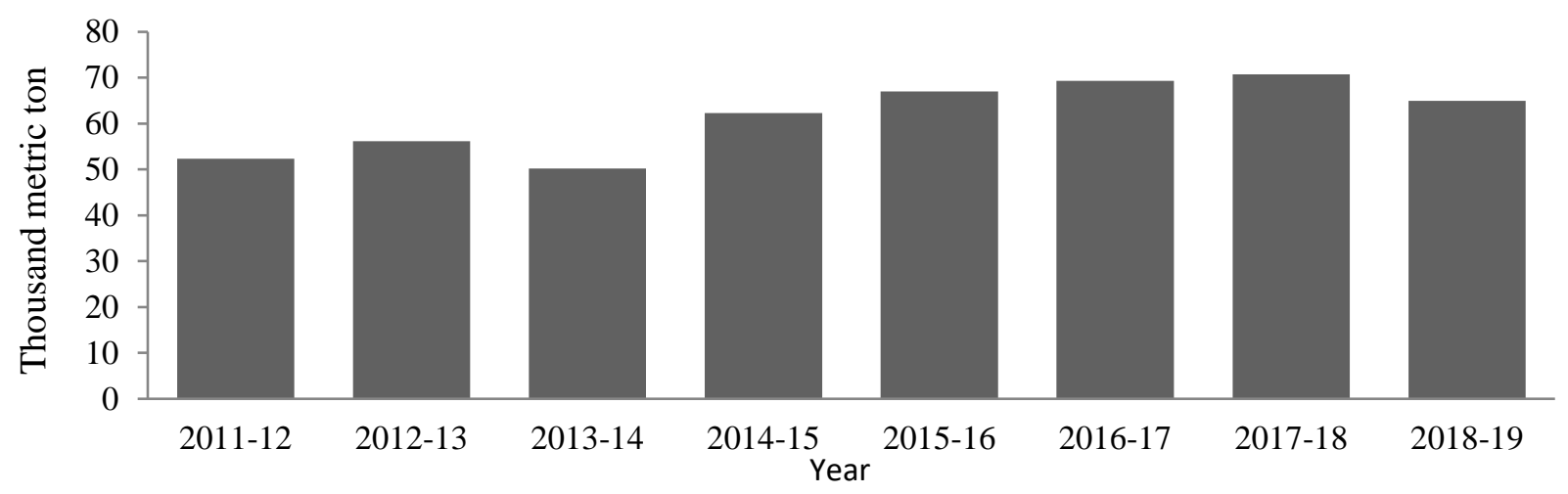

Figure 1. Fish production from inland waters of Sylhet district from 2011-12 to 2018-19 (data source: DoF, 2018)

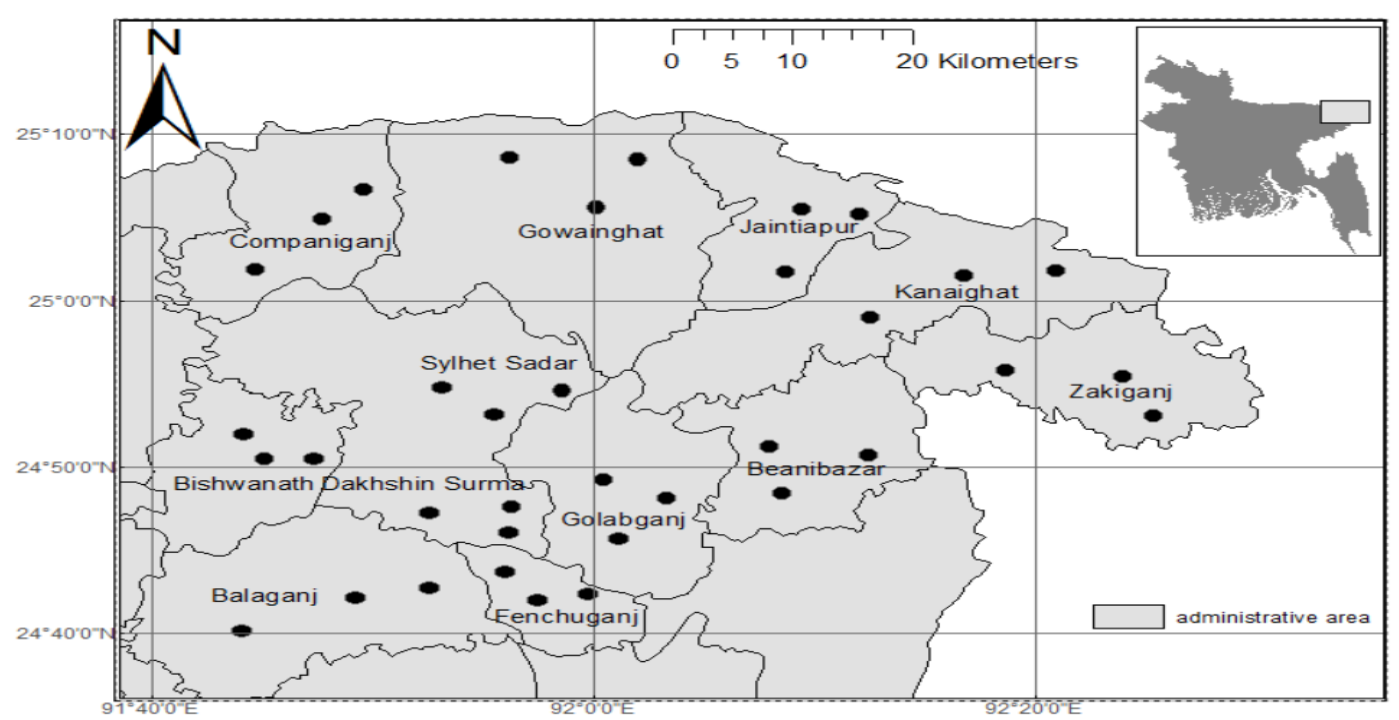

Figure 2. Study area and Upazilla map of Sylhet district (black circles showing the farm locations) 
from each farm). There were 5-13 farmers/ farm workers in each studied farms depending on the size of the farms.

\section{Sampling and Data Collection}

Questionnaire interviews and participatory rural appraisal (PRA) tool i.e., focus group discussion (FGD), were conducted with farmers and farm managers to collect the relevant primary data.

\section{Questionnaire Interview}

The questionnaire interview was conducted with a semi-structured and open-ended questionnaire. The farmers, as the interviewee, were selected by using the simple random sampling technique to collect data, mostly qualitative. Local language and units of measurement were used during face-to-face interviews for the proper apprehension of the respondents to minimize errors, which were then converted appropriately. There were no interpreters used because the authors could communicate in the local language fluently, which helped to reduce potential biases due to personal and social interactions. Apart from the same semi-structured questionnaire just as farmers, another questionnaire was prepared to collect the quantitative data and disease score (on a scale of five) from the associated farm managers.

\section{Focus Group Discussion (FGD)}

Focus group discussion (FGD) was conducted with fish farmers to get accurate information about aquaculture practices and fish health management. Total 12 FGD sessions (one in each Upazilla) were arranged, and there were 5-6 farmers/ farm workers in each focus group. The FGD sessions were held in front of the house of farmers or adjacent markets. The required information was written simultaneously during FGD; however, those sessions were also audio recorded as a precautionary approach.

\section{Cross-Check Interview}

Cross-check interviews were carried with key informants (37, District Fisheries Officer and 3 in each Upazilla)- Upazilla Fisheries Officer, associated NGO workers, fish traders, and leader of fisher's community with the same questionnaire. However, some information was unknown to them, and some did not match the response from farmers and farm managers.

\section{Data Analysis}

The data was categorized meaningfully following the objective of the study. Percentage and arithmetic mean were calculated whenever necessary. The stocking density, annual production, and expenditure to tackle diseases in different size farms, and the disease score, farm size, stocking density, annual production, and expenditure to tackle diseases in different farms Upazilla- wise were analyzed by Kruskal- Wallis test followed by the Dunn test as post- Hoc test $(P<0.05)$. The correlation among different parameters was run using Spearman's correlation. The categorized data were statistically analyzed and plotted using SPSS version 22 and Microsoft excel 2010, respectively.

\section{Results}

\section{Status of Farms and Farmers}

It was observed that for the highest number of cases, the farm area was owned by the owner of the respective farm $(50 \%)$, followed by the farm owner leased the farm area from other landowners or government (28\%). However, about $22 \%$ of the farm owners had partly owned and partly leased the farm area. Among farmers/ farm workers $(n=180)$, about $64 \%$ of the total had their aquaculture management training at least once from concerning governmental and non-governmental organizations. However, only about $30.5 \%$ of the farm managers $(n=36)$ had such training experiences. Among 36 fish farms, most of the farms produced their fry, followed by the collection of fry from other farms, wild-caught generally from adjacent water bodies and haor of Sunamganj, bought from local traders, governmental and private hatcheries (Figure 3A). For farms that used their brood fish to produce fry, a higher proportion (53.9\%) had their brood fish for spawning, followed by brood fish collected from wild (30.8\%) and other farms (15.4\%).

Small farms ( $\leq 2$ ha) were found to practice monoculture (generally Anabas testudineus, mono-sex tilapia, Pangasius pangasius, and Heteropneustes fossilis) whereas medium (2.1- $3.5 \mathrm{ha}$ ) and large ( $\geq 3.5$ ha) farms practice both polyculture (generally indigenous and exotic carp species) and monoculture. Small farms spent the least to prevent disease $(P<0.05)$. However, the stocking density and production were higher in small farms, which was followed by medium and large farms $(P<0.05$, Table 1$)$. Most farms (83.33\%) were observed to supply local feed- rice bran, meat bone, wheat bran, mustard oil cake with vitamin premix. However, few farms (16.67\%), mostly small private ones, fed the fish with commercial feeds (1- 2 times/day of feeding frequency).

\section{Diseases in Farms}

Most of the farmers (95.8\%) monitor the health of fish, either weekly or monthly. The most prevalent reasons for fish mortality showing clinical signs of disease, which are observed by farmers and farm managers, are- Epizootic ulcerative syndrome (EUS), which was followed by environmental, argulosis, nutritional, dropsy and fin and tail rot (Figure 3B). 


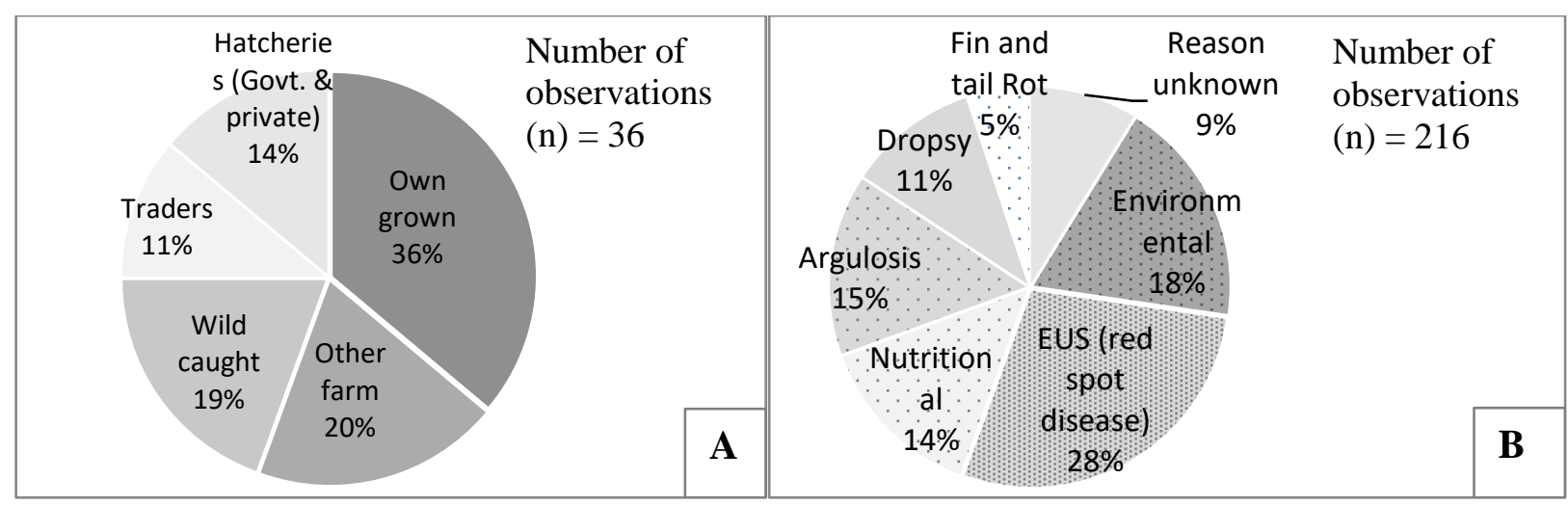

Figure 3. (A) sources of fish fry in farms and (B) disease outbreak in fish farms

Table 1. Fish farming in farms of different sizes, including stocking density, production and average expenditure (mean \pm standard deviation). Different superscripts in the same column indicate significant differences $(P<0.05)$

\begin{tabular}{|c|c|c|c|c|c|c|c|}
\hline $\begin{array}{l}\text { Farm size } \\
\text { (ha) }\end{array}$ & $\begin{array}{l}\text { Farms } \\
(\%)\end{array}$ & $\begin{array}{l}\text { Culture } \\
\text { system }\end{array}$ & Culture practices & $\begin{array}{l}\text { Type of } \\
\text { farms }\end{array}$ & $\begin{array}{c}\text { Stocking } \\
\text { density (no. } \\
\text { ha-1) }^{-1}\end{array}$ & $\begin{array}{l}\text { Production } \\
\left(\mathrm{kg} \mathrm{ha}^{-1} \text { year }^{-1}\right)\end{array}$ & $\begin{array}{c}\text { Average } \\
\text { expenditure to } \\
\text { prevent disease } \\
\text { USD ha- } \text { year }^{-1}\end{array}$ \\
\hline$\leq 2$ & 41.7 & Intensive & Monculture & Private & $40980 \pm 778^{a}$ & $20677 \pm 687^{a}$ & $12 \pm 2^{b}$ \\
\hline $2.1-3.5$ & 38.9 & $\begin{array}{c}\text { Intensive, } \\
\text { Semi- } \\
\text { intensive } \\
\end{array}$ & $\begin{array}{l}\text { Polyculture, } \\
\text { monculture }\end{array}$ & Private & $18707 \pm 608^{b}$ & $10961 \pm 592^{b}$ & $80 \pm 14^{a}$ \\
\hline$\geq 3.5$ & 19.4 & $\begin{array}{c}\text { Semi- } \\
\text { intensive, } \\
\text { Extensive }\end{array}$ & $\begin{array}{l}\text { Polyculture, } \\
\text { monculture }\end{array}$ & $\begin{array}{l}\text { Private, } \\
\text { Public }\end{array}$ & $14214 \pm 756^{c}$ & $\begin{array}{c}9014 \pm \\
659^{c}\end{array}$ & $73 \pm 21^{a}$ \\
\hline
\end{tabular}

\section{Upazilla-Wise Status}

The size, production, disease score, and density were not significantly different at studied farms of different Upazilla ( $P>0.05$, Figure 4). However, average expenditure in different Upazilla was significantly different $(P<0.05)$. Farms in Balaganj, Zakiganj, Beanibazar, Companiganj, and Bishwanath spent less to prevent disease than farms in other Upazilla (Figure 4). The disease score was negatively correlated with farm size (correlation value: $-0.895, \mathrm{P}<0.001$ ), expenditure (correlation value: $-0.673, \mathrm{P}<0.05$ ) and production (correlation value: $-0.837, \mathrm{P}<0.001$ ). The production in farms of different Upazilla positively correlated with expenditure to prevent disease (correlation value: $0.608, \mathrm{P}<0.05)$.

\section{Chemicals Used in the Farm}

Most of the farms used lime and salt, followed by other traditional chemicals such as potash, fertilizers and Sumithione for preparing the culture unit (Figure $5 \mathrm{~A})$. On the other hand, Gasonil and Rotaplus were used by the maximum proportion of studies farms, whereas Bio- ox was used by the least (Figure 5B).

The traditional and commercial chemicals/ medicines were used for different purposes and dosage (Table 2). The doses are generally prescribed by the manufacturer on the package or the experts e.g.,
Upazila Fisheries Officer. Farm managers generally ensure that the doses of these chemicals are within the prescribed limit.

\section{Seasonal Effects}

There were variations in opinion about the possible seasonal effect on disease among farm respondents ( $n=$ 216). Most of the respondents (27.78\%) suspected the winter season facilitates diseases, followed by summer (21.3\%) and rainy (14.81\%) seasons. However, some respondents thought there was no effect $(21.3 \%)$, and some were not sure about the effect (14.81\%) of seasons on disease outbreak.

\section{Prescribed Solutions by Respondents}

Most of the total respondents $(n=216)$ mentioned financial assistance or loans (58.33\%), proper education/training to farmers and managers (52.78\%), and technical assistance from associated governmental or non-governmental organizations $(50.46 \%)$ could enhance the production and ameliorate fish diseases. Some respondents also prescribed that the development of new infrastructures $(21.76 \%)$, provision of medicines and chemicals (22.22\%), regular water changing facilities (11.57\%), and maintenance of proper sanitation and hygiene $(4.17 \%)$ could contribute to the purpose. 


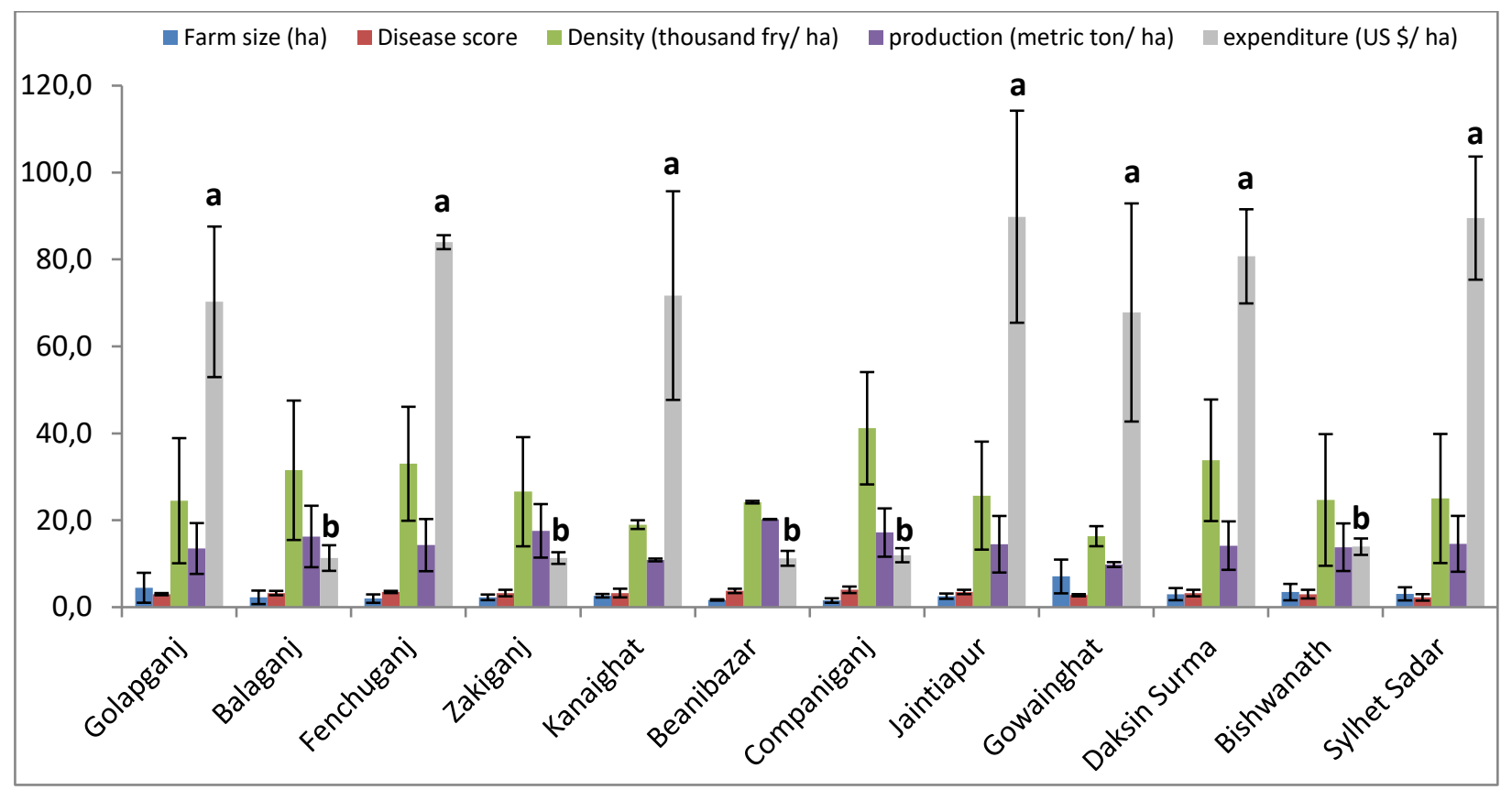

Figure 4. Variation in farm size, disease score, density, production and expenditure to prevent disease at different studied farms of different Upazilla. Different superscripts in the same parameter for different upazilla show significant differences $(P<0.05)$

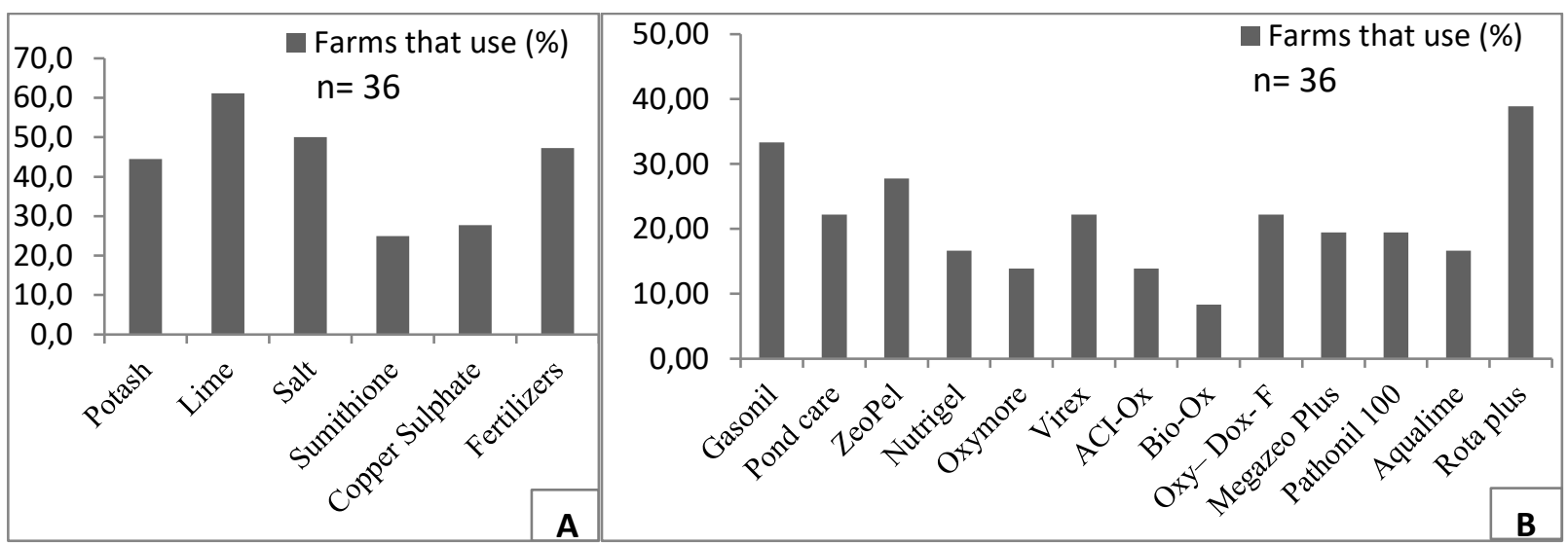

Figure 5. Percentages of farms that use respective chemicals/ medicine (A) Traditional chemicals and (B) Commercial chemicals/ medicines

\section{Discussions}

The study showed a range of diseases and farm management in rural freshwater of Sylhet, Bangladesh, as was reported by aquaculture farmers/ workers and managers regarding their experience and incidents that occurred in farms. Various types of diseases in freshwater aquaculture farming in the Sylhet district were identified from the study. Epizootic ulcerative syndrome (EUS) was the most dominant disease in studied farms, followed by Argulosis, tail and fin rot, dropsy, and environmental diseases. Resembling conditions are also reported in the aquaculture farms of other districts in Bangladesh by several authors (Faruk et al., 2004; Hasan et al., 2013). The pathology of EUS includes the development of red spots on the skin (Yadav et al., 1992). Most farm managers and farmers named it "ulcer" and can easily recognize the disease when it appears. To solve this problem, locally available materials such as lime, ash, salt, and a combination of lime and salt are being used during culture unit preparation. The application of these cheap local materials reduced the prevalence of diseases and helped infected fish recover in some cases (Nandeesha et al., 2002). Bacterial infections were also common, and one of the most challenging health problems to deal with. These bacteria become pathogenic when fishes are pathogenically unbalanced, nutritionally deficient, or there are other stressors i.e., poor water quality, overstocking, which allow an opportunistic bacterial infection to proceed (information acquired from the different Upazila Fisheries Officers, UFO).

Though the stocking density and production were higher in small intensive farms practicing monoculture than medium and large scale farms, the expenditure to prevent disease was higher in medium and large scale farms. This does not necessarily mean that small farms have better farming conditions and management than 
medium and large farms. Monoculture was commonly practiced with catfishes and other hardy fishes that can survive diseases and environmental shock compared to exotic and indigenous carps, as is observed among these fish in a natural environment (Tiwari et al., 2016). Though the small private farms are unable to pay much attention and money in preventing and tackling fish diseases, the production might become higher due to the hardy nature of those cultured fish due to very high stocking density. Because the expenditure to prevent disease positively correlated with the production and negatively correlated with disease scores, it can be assumed that expenses to prevent fish diseases and water quality degradation helped to enhance the production and control of the disease. On the other hand, disease scores in different farms decreased with the increased farm size and reduction in stocking density, which is suggesting a possibility of increased disease outbreaks in intensive farms with higher stocking density. However, there were no significant differences in disease score in different farms Upazilla wise. Stocking of different fish (polyculture) increases the chances of collecting seeds from different sources, raising the possibilities of disease introduction and transmission. Therefore, fish seeds collected from broodstock of wild-caught and own grown were also mentioned by the respondents as the reason behind minimal occurrences of diseases in some farms. Besides, poor management by inexperienced fish farmers, low input, and poor understanding of fish health management can be other factors. The environmental condition, including water quality management, undoubtedly affect the health condition of cultured fish. Good management of water quality can surely reduce the stress level and risk of fish diseases and parasites. In most of the farms, pond water quality often degrades, including increasing ammonia contents due to increasing uneaten feed and faeces accumulation, reduction in $\mathrm{pH}$, and hypoxia (information shared by UFO). This kind of water pollution can facilitate disease outbreaks in acute form and mass mortality (Austin, 1998). An extensive range of farms does not usually check the water quality parameters, even if it becomes necessary when water quality degrades. This is probably because they do not have appropriate knowledge, facilities, and instruments to measure water quality parameters. The water quality in some farms did not seem to be visually suitable for culturing fish. Besides, the source of water can also affect cultured fish. In particular, water may be contaminated with heavy metals, agrochemical pollutants and harmful pathogens, which may affect fish health and production (Rajaganapathy et al., 2011). According to most of the fish farmers, most of the outbreak of diseases occurred during winter, probably because the water level of ponds dropped to the minimum, and eventually, the water quality may have degraded. As a result, the severity of environmental and infectious diseases, including EUS, rose and caused the mortality of fish
(Choongo et al., 2009). In particular, the temperature can also be a factor exerting stress in cultured fish (Le Morvan et al., 1998), resulting in increased susceptibility to diseases.

In the present study, the reporting of fish disease in some farms was surprisingly low, not because of the lower outbreak of diseases but due to lack of recordkeeping and ignorance of the possible severity of fish diseases. Due to a lack of assistance from fish health experts and diagnostic laboratory, there was a severe lack of preventive measures and treatments to tackle diseases observed. The prompt response from some farmers/ workers to disease outbreak was generally the application of chemicals with little understanding of the dose effectiveness and possible side effects; better results seemed to be found by changes in management practices. Lacking proper aquaculture management and indiscriminate use of chemicals can also be a possible cause for the degradation of surrounding natural environments and the possibility of disease transmission from aquaculture to the wild, possibly through escaped fish from culture unit or spread through rainwater and seasonal flooding. (Bouwmeester et al., 2020; Leung \& Bates, 2013). Motavalli \& DeBlanc-Knowles (2003) reported that only $5 \%$ of the sprayed chemicals reach the targeted organisms. The rest 95\% remained in the surrounding areas and can ultimately become an environmental contaminant.

Farmers and farm managers mentioned that assistance from fisheries extension services, fish health experts, concerning governmental organizations (GOs), and non-governmental organizations (NGOs) were low. Mainly the poor (lease waterbodies from others and solely dependent on the farm) and inexperienced farm managers and farmers seemed to suffer more from the adverse effects of disease outbreaks. Farmers and managers from some farms have a better understanding of fish health and aquaculture management practices, which are deemed to reduce the introduction and impact of fish diseases. In particular, for all the studied public farms, farm managers have an adequate degree, knowledge, and experience regarding aquaculture management (assessed and appointed by the government). As a result, better aquaculture practices were observed in public farms. Managerial skill and ability were found to affect the overall management and financial gain in aquaculture (Rahman et al., 2020). On the other hand, most of the private farms were found to be managed by the farm owners. Most of the private managers did not have appropriate knowledge and experience regarding aquaculture management practices. Besides, proper training of farmers and farm managers in health management practices can be effective in tackling diseases. Subasinghe et al. (2001) found that the short and long-term training in fish health and aquaculture management has increased, however relatively low compared to the rapid intensification of aquaculture. In our experiment, we found more fish farmers received training regarding aquaculture 
Table 2. Commonly used traditional and commercial chemicals/medicines with doses and purposes

\begin{tabular}{|c|c|c|c|}
\hline $\begin{array}{l}\text { Trade/common } \\
\text { name }\end{array}$ & Chemical/ Biological composition & Doses & Purposes \\
\hline Potash & $\mathrm{KMnO}_{4}$ & $0.13-0.38 \mathrm{mg} \mathrm{m}^{-2}$ & Disinfectant \\
\hline Lime & $\mathrm{CaO}, \mathrm{Ca}(\mathrm{OH})_{2}$ & $25-50 \mathrm{~g} \mathrm{~m}^{-2}$ & $\begin{array}{c}\text { Ectoparasiticide, Fungicide and } \\
\text { maintaining } \mathrm{pH}\end{array}$ \\
\hline Salt & $\mathrm{NaCl}$ & $12.5-25 \mathrm{~g} \mathrm{~m}^{-2}$ & $\begin{array}{c}\text { Disinfectants, Ectoparasiticide, and } \\
\text { Fungicides }\end{array}$ \\
\hline Sumithione & Fenitrothion $\left(\mathrm{C}_{9} \mathrm{H}_{12} \mathrm{NO}_{5} \mathrm{PS}\right)$ & $0.07-0.09 \mathrm{ml} \mathrm{m}^{-2}$ & Pesticide \\
\hline $\begin{array}{l}\text { Copper } \\
\text { Sulphate }\end{array}$ & $\mathrm{CuSO}_{4}$ & $0.37-0.61 \mathrm{mg} \mathrm{m}^{-2}$ & Weed control and Ectoparasiticide \\
\hline Fertilizers & $\begin{array}{c}\text { Triple Superphosphate, Urea and Muriate } \\
\text { of Potash }\end{array}$ & $2.5-3.75 \mathrm{~g} \mathrm{~m}^{-2}$ & Increase primary productivity \\
\hline Gasonil & Probiotics & $\begin{array}{l}0.04-0.05 \mathrm{~g} \mathrm{~m}^{-2} \\
\text { (depth: } 1-1.5 \mathrm{~m} \text { ) }\end{array}$ & $\begin{array}{c}\text { Fish growth, reduce harmful gas and } \\
\text { weeds }\end{array}$ \\
\hline Pond care & Probiotics & $\begin{array}{l}0.19-0.20 \mathrm{~g} \mathrm{~m}^{-2} \\
\text { (depth: } 1-1.5 \mathrm{~m} \text { ) }\end{array}$ & $\begin{array}{l}\text { Fish growth, control of } \mathrm{pH} \text { and } \\
\text { weeds }\end{array}$ \\
\hline ZeoPel & $\begin{array}{c}\mathrm{SiO} 2, \mathrm{Al} 2 \mathrm{O} 3, \mathrm{Fe} 2 \mathrm{O} 3, \mathrm{CaO}, \mathrm{MgO}, \mathrm{Na}_{2} \mathrm{O}_{3}, \\
\mathrm{~K}_{2} \mathrm{O}\end{array}$ & $\begin{array}{l}6.17-7.40 \mathrm{~g} \mathrm{~m}^{-2} \\
\text { (depth: } 1-1.5 \mathrm{~m} \text { ) }\end{array}$ & Control of gas and $\mathrm{pH}$ \\
\hline Nutrigel & $\begin{array}{l}\text { Vitamins, Minerals \& Probiotics rich Feed } \\
\text { Binder }\end{array}$ & $0.50-1.0 \mathrm{~g} \mathrm{~kg}^{-1}$ feed & Provide minerals and vitamins \\
\hline Oxymore & $\begin{array}{l}\text { 90\% Sodium Carbonate Peroxyhydrate, } \\
12 \% \text { Active Oxygen }\end{array}$ & $\begin{array}{l}0.13-0.19 \mathrm{~g} \mathrm{~m}^{-2} \\
\text { (depth: } 1-1.5 \mathrm{~m} \text { ) }\end{array}$ & Control oxygen level \\
\hline Virex & $50 \%$ Oxy mono-sulphate, $5 \% \mathrm{C}_{3} \mathrm{C}_{12} \mathrm{~N}_{3} \mathrm{NaO}_{3}$ & $\begin{array}{l}0.02-0.03 \mathrm{~g} \mathrm{~m}^{-2} \\
\text { (depth: } 1.5-2 \mathrm{~m} \text { ) }\end{array}$ & Act as disinfectant \\
\hline $\mathrm{ACl}-\mathrm{Ox}$ & $\begin{array}{c}2 \mathrm{Na}_{2} \mathrm{CO}_{3} .3 \mathrm{H}_{2} \mathrm{O}_{3}, 83 \% \mathrm{Na}_{2} \mathrm{CO}_{3} \text { and } 17 \% \\
\mathrm{H}_{2} \mathrm{O}_{2}\end{array}$ & $0.06-0.12 \mathrm{~g} \mathrm{~m}^{-2}$ & Control oxygen level \\
\hline Bio-Ox & $2 \mathrm{Na}_{2} \mathrm{CO}_{3} \cdot 3 \mathrm{H}_{2} \mathrm{O}_{2}$ & $0.07-0.09 \mathrm{~g} \mathrm{~m}^{-2}$ & Control oxygen Level \\
\hline Oxy-Dox- F & $20 \% \mathrm{C}_{22} \mathrm{H}_{24} \mathrm{~N}_{2} \mathrm{O}_{9}$ & $0.50-0.75 \mathrm{~g} \mathrm{~kg}^{-1}$ feed & Antibiotics \\
\hline $\begin{array}{l}\text { Megazeo } \\
\text { Plus }\end{array}$ & $\mathrm{SiO}_{2}, \mathrm{CaO}$ & $\begin{array}{c}\text { 5- } 6 \mathrm{~g} \mathrm{~m}^{-2} \\
\text { (depth: } 1-1.5 \mathrm{~m} \text { ) }\end{array}$ & $\begin{array}{c}\text { Control of } \mathrm{pH} \text { and increase food } \\
\text { conversion efficiency }\end{array}$ \\
\hline $\begin{array}{l}\text { Pathonil } \\
100\end{array}$ & $80 \%$ Benzalkonium chloride & $\begin{array}{l}0.15-0.18 \mathrm{ml} \mathrm{m} \mathrm{m}^{-2} \\
\text { (depth: } 1.5-2 \mathrm{~m} \text { ) }\end{array}$ & $\begin{array}{l}\text { Protect from Fin tail rot } \\
\text { Disease }\end{array}$ \\
\hline Aqualime & $\mathrm{CaO}$ & $\begin{array}{c}\text { 7- } 12 \mathrm{~g} \mathrm{~m}^{-2} \\
\text { (depth: } 1-1.5 \mathrm{~m} \text { ) }\end{array}$ & Balance $\mathrm{pH}$ \\
\hline Rota plus & $\begin{array}{c}\text { Organic elements derived from derris } \\
\text { tree }\end{array}$ & $0.5-0.6 \mathrm{~g} \mathrm{ft}^{-1} \mathrm{~m}^{-2}$ & Destroy predatory fish \\
\hline
\end{tabular}

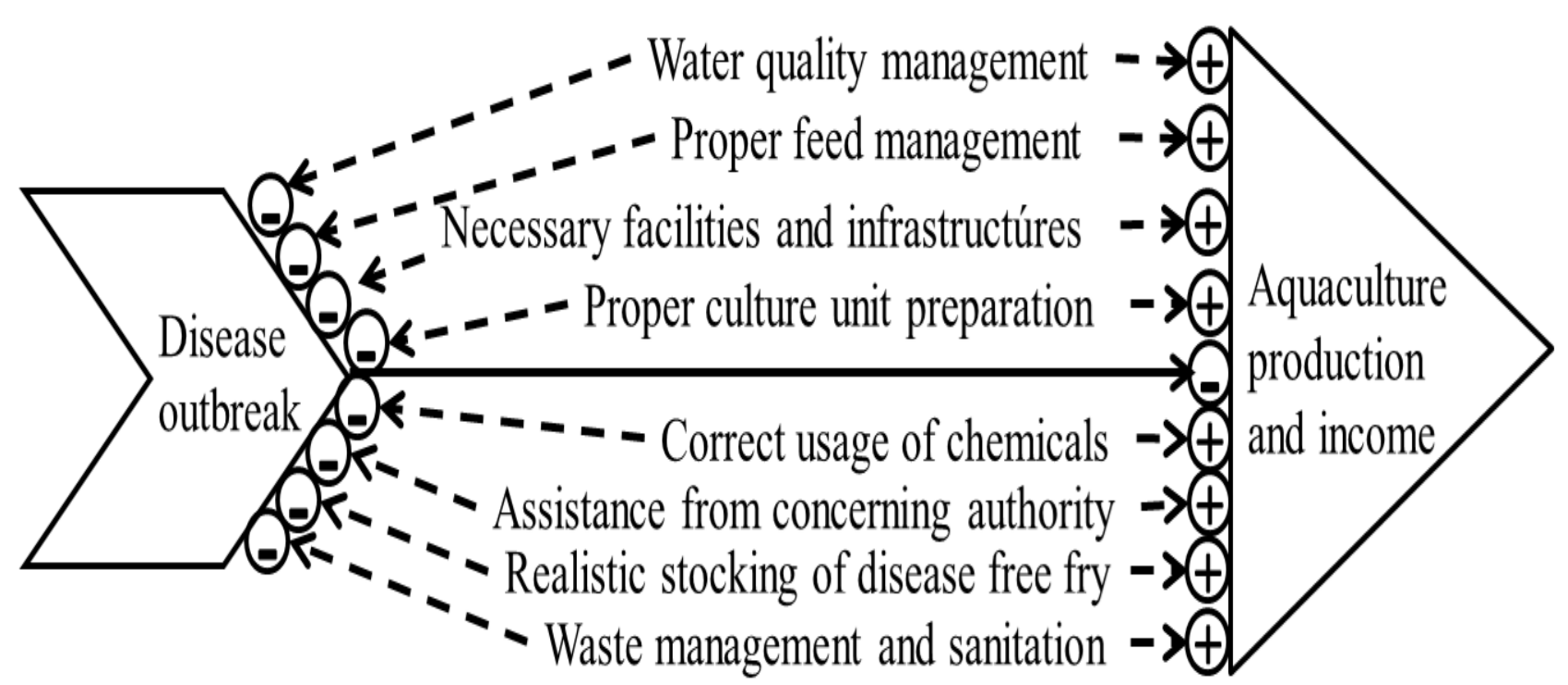

Figure 6. Cause-effect diagram relating fish disease to aquaculture production and income 
management compared to farm managers (except public farms). Because sometimes concerning GOs and NGOs arrange some training programs, in which they offer money and/or food to the participants. While affluent farm managers are reluctant to join these training programs, poor farmers get attracted and generally participated.

The reduction in disease outbreak and increase in production can be best achieved through the use of realistic stocking densities, stocking disease-free seeds, preventing the introduction of pathogens, maintenance of water quality, avoiding stress, and through the provision of adequate nutrition to cultured animals (suggested by respondents and key informants, Figure 6). Composite "Water quality testing- disease diagnosis laboratory", at every Upazilla level, especially regions practicing aquaculture, can be established to tackle the magnitude of the disease outbreak (Mishra et al., 2017).

\section{Conclusions}

In the present study, though severe underreporting of fish diseases assumed in different farms, small farms seemed to pay less attention and money in preventing diseases than medium and large farms. However, spending time and efforts to prevent disease and maintain suitable water quality can enhance productivity in the long run. Farming conditions can be improved by helping stakeholders with appropriate training and assistance. Future studies should assess the economics of aquaculture farms in-depth and identify the abnormalities by analyzing cultured fish and water samples properly.

\section{Ethical Statement}

Ethical approval was not required regionally or nationally. This was a survey-based study, and no animals were harmed or killed during the study.

\section{Funding Information}

Work partially funded by Sylhet Agricultural University Research System (UGC-SAURES) authority. The funders had no role in study design, data collection and analysis, decision to publish, or preparation of the manuscript.

\section{Author Contributions}

AD: Conceptualization, writing- original draft, data collection; CSSC: conceptualization, writing- original draft and editing, data analysis and visualization; PR: Data collection and curation, methodology, formal analysis, writing- review and editing; MIH: Supervision, Writing - review and editing; SMB: Funding acquisition, Supervision, Writing - review, and editing.

\section{Conflict of Interest}

The authors declare that they have no known competing financial or non-financial, professional, or personal conflicts that could have appeared to influence the work reported in this paper.

\section{References}

Aftabuddin, S., Islam, M. N., Bhuyain, M. A. B., Mannan, M. A., \& Alam, M. M. (2016). Fish diseases and strategies taken by the farmers in freshwater aquaculture at southwestern Bangladesh. Bangladesh Journal of Zoology, 44(1), 111-122.

Alam, M. A., \& Guttormsen, A. G. (2019). Risk in aquaculture: farmers' perceptions and management strategies in Bangladesh. Aquaculture Economics \& Management, 23(4), 359-381.

Austin, B. (1998). The effects of pollution on fish health. Journal of Applied Microbiology, 85(S1), 234S-242S. https://doi.org/10.1111/j.1365-2672.1998.tb05303.x

Bouwmeester, M. M., Goedknegt, M. A., Poulin, R., \& Thieltges, D. W. (2020). Collateral diseases: aquaculture impacts on wildlife infections. Journal of Applied Ecology.

Brown, D., \& Brooks, A. (2002). A Survey of Disease Impact and Awareness in Pond Aquaculture in Bangladesh, the Fisheries Training and Extension Project-Phase II. FAO Fisheries Technical Paper, 85-93.

Choongo, K., Hang'ombe, B., Samui, K. L., Syachaba, M., Phiri, H., Maguswi, C., Muyangaali, K., Bwalya, G., \& Mataa, L. (2009). Environmental and climatic factors associated with epizootic ulcerative syndrome (EUS) in fish from the Zambezi floodplains, Zambia. Bulletin of Environmental Contamination and Toxicology, 83(4), 474-478.

DoF. (2018). Yearbook of Fisheries Statistics of Bangladesh, 2017-18. Ministry of Fisheries, Bangladesh.

FAO. (2018). The State of World Fisheries and Aquaculture 2018-Meeting the sustainable development goals. FAO Rome, Italy.

Faruk, M. A. R., Alam, M. J., Sarker, M. M. R., \& Kabir, M. B. (2004). Status of fish disease and health management practices in rural freshwater aquaculture of Bangladesh. Pakistan Journal of Biological Science, 7(12), 2092-2098.

Hasan, M. M., Faruk, M. A. R., Anka, I. Z., \& Azad, M. A. K. (2013). Investigation on fish health and diseases in rural pond aquaculture in three districts of Bangladesh. Journal of the Bangladesh Agricultural University, 11(2), 377-384.

Le Morvan, C., Troutaud, D., \& Deschaux, P. (1998). Differential effects of temperature on specific and nonspecific immune defences in fish. Journal of Experimental Biology, 201(2), 165-168.

Leung, T. L. F., \& Bates, A. E. (2013). More rapid and severe disease outbreaks for aquaculture at the tropics: implications for food security. Journal of Applied Ecology, 215-222.

Mishra, S. S., Rakesh, D., Dhiman, M., Choudhary, P., Debbarma, J., Sahoo, S. N., Barua, A., Giri, B. S., Ramesh, R., \& Ananda, K. (2017). Present status of fish disease management in freshwater aquaculture in India: stateof-the-art-review. Journal of Aquaculture \& Fisheries, 1(003). https://doi.org/10.24966/AAF-5523/100003 
Motavalli, J., \& DeBlanc-Knowles, J. (2003). Clean and Green: New Zealand is a Study in Environmental Contrasts. E: The Environmental Magazine, 21-24.

Nandeesha, M. C., Haque, S., Karim, M., Saha, S. K., \& Mohan, C. V. (2002). Making health management relevant in the context of rural aquaculture development: Lessons from the CARE LIFE Project. FAO Fisheries Technical Paper, 297-312.

Rahman, M. T., Nielsen, R., Khan, M. A., \& Ankamah-Yeboah, I. (2020). Impact of management practices and managerial ability on the financial performance of aquaculture farms in Bangladesh. Aquaculture Economics \& Management, 24(1), 79-101.

Rahman, M. Z. (2014). Aquaculture drugs used for fish and shellfish health management in the Southwestern Bangladesh. Asian J. Biol. Sci, 7, 225-232.

Rajaganapathy, V., Xavier, F., Sreekumar, D., \& Mandal, P. K. (2011). Heavy metal contamination in soil, water and fodder and their presence in livestock and products: a review. Journal of Environmental Science and
Technology, 4(3), 234-249.

Subasinghe, R. P., Bondad-Reantaso, M. G., \& McGladdery, S. E. (2001). Aquaculture development, health and wealth. Subasinghe, R.P., Bueno, P., Phillips, M.J., Hough, C., McGladdery, S.E., Arthur, J.R. (Eds.). Aquaculture in the Third Millenium. Technical Proceedings of the Conference on Aquaculture in the Third Millenium, Bangkok, Thailand, 20-25 February 2000. http://www.fao.org/DOCREP/003/AB412E/\%0Aab412e 09.htm

Tiwari, A., Dwivedi, A. C., \& Mayank, P. (2016). Time scale changes in the water quality of the Ganga River, India and estimation of suitability for exotic and hardy fishes. Hydrology Current Research, 7(3), 254.

Yadav, M., Indira, G., \& Ansary, A. (1992). Cytotoxin elaboration by Aeromonas hydrophila isolated from fish with epizootic ulcerative syndrome. Journal of Fish Diseases, 15(2), 183-189.

https://doi.org/10.1111/j.1365-2761.1992.tb00652.x 